Check for updates

Cite this: J. Mater. Chem. A, 2019, 7, 21244

Received 12th June 2019

Accepted 24th August 2019

DOI: 10.1039/c9ta06291b

rsc.li/materials-a

\section{Improved cycling stability in high-capacity Li-rich vanadium containing disordered rock salt oxyfluoride cathodes $\uparrow$}

\author{
Christian Baur, (D) *a Ida Källquist, (DD ${ }^{\mathrm{b}}$ Johann Chable, $^{\mathrm{a}}$ Jin Hyun Chang, (D) c \\ Rune E. Johnsen, (D) ${ }^{c}$ Francisco Ruiz-Zepeda, (D) d Jean-Marcel Ateba Mba, ${ }^{d}$ \\ Andrew J. Naylor, (DD) Juan Maria Garcia-Lastra, (DD c Tejs Vegge, (iD c Franziska Klein, ${ }^{\text {a }}$ \\ Annika R. Schür, ${ }^{a}$ Poul Norby, ${ }^{c}$ Kristina Edström, ${ }^{e}$ Maria Hahlin (DD b \\ and Maximilian Fichtner (D) af
}

Lithium-rich transition metal disordered rock salt (DRS) oxyfluorides have the potential to lessen one large bottleneck for lithium ion batteries by improving the cathode capacity. However, irreversible reactions at the electrode/electrolyte interface have so far led to fast capacity fading during electrochemical cycling. Here, we report the synthesis of two new Li-rich transition metal oxyfluorides $\mathrm{Li}_{2} \mathrm{~V}_{0.5} \mathrm{Ti}_{0.5} \mathrm{O}_{2} \mathrm{~F}$ and $\mathrm{Li}_{2} \mathrm{~V}_{0.5} \mathrm{Fe}_{0.5} \mathrm{O}_{2} \mathrm{~F}$ using the mechanochemical ball milling procedure. Both materials show substantially improved cycling stability compared to $\mathrm{Li}_{2} \mathrm{VO}_{2} \mathrm{~F}$. Rietveld refinements of synchrotron X-ray diffraction patterns reveal the DRS structure of the materials. Based on density functional theory (DFT) calculations, we demonstrate that substitution of $\mathrm{V}^{3+}$ with $\mathrm{Ti}^{3+}$ and $\mathrm{Fe}^{3+}$ favors disordering of the mixed metastable DRS oxyfluoride phase. Hard X-ray photoelectron spectroscopy shows that the substitution stabilizes the active material electrode particle surface and increases the reversibility of the $\mathrm{V}^{3+} / \mathrm{V}^{5+}$ redox couple. This work presents a strategy for stabilization of the DRS structure leading to improved electrochemical cyclability of the materials.

\section{Introduction}

Lithium-ion batteries (LIBs) are the most widely used energy storage systems for applications in electric transportation and

${ }^{a}$ Helmholtz Institute Ulm for Electrochemical Energy Storage, Helmholtzstraße 11, 89081 Ulm, Germany. E-mail: christian.baur@kit.edu

${ }^{b}$ Uppsala University, Department of Physics and Astronomy, P. O. box 256, SE-751 05 Uppsala, Sweden

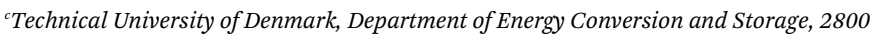
Kgs. Lyngby, Denmark

${ }^{d}$ National Institute of Chemistry, Hajdrihova 19, P. O. box 660, SI-1000 Ljubljana, Slovenia

'Department of Chemistry, Ångström Laboratory, Uppsala University, Box 538, 75121 Uppsala, Sweden

IInstitute of Nanotechnology, Karlsruhe Institute for Technology, P. O. box 3640, 76021 Karlsruhe, Germany

$\dagger$ Electronic supplementary information (ESI) available: PXRD pattern of ceramic synthesis attempts; structural parameters of the Rietveld refinements; PXRD pattern of $\mathrm{Li}_{2} \mathrm{VO}_{2} \mathrm{~F}$ with Rietveld refinement; Williamson-Hall-plots; TEM and EDX analysis; $\mathrm{SQS}$ of $\mathrm{Li}_{2} \mathrm{TMO}_{2} \mathrm{~F}$ and $\mathrm{Li}_{2} \mathrm{TM}_{0.5} \mathrm{TM}_{0.5} \mathrm{O}_{2} \mathrm{~F}$; ordered structures of $\mathrm{Li}_{2} \mathrm{TM} 1_{0.5} \mathrm{TM} 2_{0.5} \mathrm{O}_{2} \mathrm{~F}$; table of energy difference between the ordered/decomposed state and disordered state; table of oxidation states of TMs; voltage profiles of $\mathrm{Li}_{2} \mathrm{VO}_{2} \mathrm{~F}, \mathrm{Li}_{2} \mathrm{~V}_{0.5} \mathrm{Ti}_{0.5} \mathrm{O}_{2} \mathrm{~F}$ and $\mathrm{Li}_{2} \mathrm{~V}_{0.5} \mathrm{Fe}_{0.5} \mathrm{O}_{2} \mathrm{~F}$ half-cells cycled up to $4.1 \mathrm{~V}$; PXRD pattern of cycled electrodes; HAXPES Fe 2p peak fitting; HAXPES survey of $\mathrm{Li}_{2} \mathrm{~V}_{0.5} \mathrm{Fe}_{0.5} \mathrm{O}_{2} \mathrm{~F}$ and $\mathrm{Li}_{2} \mathrm{VO}_{2} \mathrm{~F}$ and fluorine plasmon overlaps with the $\mathrm{Fe} 2 \mathrm{p}_{3 / 2}$ peak; core level photoelectron spectra of $\mathrm{Fe} 2 \mathrm{p}$ and $\mathrm{Ti}$ 2p; cycling performance of $\mathrm{Li}_{2} \mathrm{VO}_{2} \mathrm{~F}, \mathrm{Li}_{2} \mathrm{~V}_{0.5} \mathrm{Ti}_{0.5} \mathrm{O}_{2} \mathrm{~F}$ and $\mathrm{Li}_{2} \mathrm{~V}_{0.5} \mathrm{Fe}_{0.5} \mathrm{O}_{2} \mathrm{~F}$ half-cells cycled up to $4.5 \mathrm{~V}$. See DOI: $10.1039 / \mathrm{c} 9$ ta06291b portable electronic devices. ${ }^{\mathbf{1 , 2}}$ Cathode materials for LIBs need to meet high energy and power density criteria for several applications and are the main focus of current research activities. $^{1,3,4}$ In 2015, the lithium-rich disordered rock salt (DRS) $\mathrm{Li}_{2} \mathrm{VO}_{2} \mathrm{~F}$ was identified as a promising cathode material with a high theoretical capacity of $462 \mathrm{~mA} \mathrm{~h}^{-1}$ by Chen et al. ${ }^{5}$ This compound exhibits a DRS structure where Li and V ions appear to be randomly distributed at the same crystallographic site in the crystal structure. ${ }^{6}$ The lithium-excess (Li : TM-ratio (transition metal) > 1) in DRS structures enables percolating pathways for Li-ions to diffuse through the structure, facilitating their use as battery materials with relatively high capacities. ${ }^{7,8} \mathrm{Li}_{2} \mathrm{VO}_{2} \mathrm{~F}$ was the first material reported in the class of Li-rich DRS materials and the first material to incorporate $\mathrm{F}^{-}$by partly substituting $\mathrm{O}^{2-}$ to lower the oxidation state of the transition metal cation and to increase the average discharge potential. ${ }^{9}$ The capacity is expected to originate from the two-electron redox couple, $\mathrm{V}^{3+} / \mathrm{V}^{5+}$, leading to practical capacities over $300 \mathrm{~mA} \mathrm{~h} \mathrm{~g}{ }^{-1}$, considerably higher than what is observed for conventional cathode materials such as $\mathrm{LiCoO}_{2}$ and $\mathrm{LiFePO}_{4}$ (140 $\mathrm{mA} \mathrm{h} \mathrm{g}^{-1}$ and $\left.170 \mathrm{~mA} \mathrm{~h} \mathrm{~g}^{-1}\right) .{ }^{1-3}$

Many different compounds with the Li-rich DRS phase have been reported since the original study. Materials like $\mathrm{Li}_{1.3} \mathrm{Nb}_{0.3} \mathrm{TM}_{0.4} \mathrm{O}_{2}\left(\mathrm{TM}=\mathrm{Fe}^{3+}, \mathrm{Mn}^{3+}, \mathrm{V}^{3+}\right)$ and $\mathrm{Li}_{1.2} \mathrm{Ni}_{1 / 3} \mathrm{Ti}_{1 / 3} \mathrm{Mo}_{2 / 15} \mathrm{O}_{2}$ have been synthesized using a classical high-temperature annealing solid-state approach. ${ }^{\mathbf{1 0 - 1 2}}$ 
These materials exhibit a relatively stable electrochemical behavior for more than 20 cycles. Fluoride-containing Li-rich DRS materials, such as $\mathrm{Li}_{2} \mathrm{VO}_{2} \mathrm{~F}, \mathrm{Li}_{2} \mathrm{Cr}_{1-x} \mathrm{~V}_{x} \mathrm{O}_{2} \mathrm{~F}(x=0-1)$, $\mathrm{Li}_{2} \mathrm{MnO}_{2} \mathrm{~F}, \mathrm{Li}_{2} \mathrm{MoO}_{2} \mathrm{~F}$ and $\mathrm{Li}_{2.1} \mathrm{Ti}_{0.2} \mathrm{Mo}_{0.7} \mathrm{O}_{2} \mathrm{~F}$, have on the other hand only been synthesized by high-energy ball milling, leading to nano-sized particles with crystallographic defects., ${ }^{5,13-17}$ Ball milled DRS oxyfluorides generally suffer from fast capacity fading and the reason for the capacity fading is still not fully understood..$^{5,15,16,18}$ Recent publications indicate that such DRS phases might be metastable. ${ }^{\mathbf{1 0 , 1 4}, \mathbf{1 9}} \mathrm{A}$ recent study of Källquist et al. identified irreversible reactions at the surface of $\mathrm{Li}_{2} \mathrm{VO}_{2} \mathrm{~F}$ with the electrolyte as the possible cause of the capacity fading. ${ }^{20}$ Herein, we propose that the key to understand the degradation mechanism of $\mathrm{Li}_{2} \mathrm{VO}_{2} \mathrm{~F}$ and other disordered rock salt oxyfluorides is linked to the metastable structure and surface stability of the DRS phase. Even though $\mathrm{Li}_{2} \mathrm{VO}_{2} \mathrm{~F}$ has a lower average discharge voltage compared to other DRS materials, its high theoretical and practical discharge capacities make it an attractive material to study. We report the synthesis of two new Li-rich DRS oxyfluoride phases, $\mathrm{Li}_{2} \mathrm{~V}_{0.5} \mathrm{Ti}_{0.5} \mathrm{O}_{2} \mathrm{~F}$ and $\mathrm{Li}_{2} \mathrm{~V}_{0.5} \mathrm{Fe}_{0.5} \mathrm{O}_{2} \mathrm{~F}$. We also elucidate alternative synthesis approaches towards a conventional solid-state synthesis of $\mathrm{Li}_{2} \mathrm{VO}_{2} \mathrm{~F}$ and substituted Li-rich DRS oxyfluorides (see ESI $\dagger$ ). LiF cannot be incorporated stoichiometrically into the structure under conventional solidstate synthesis conditions. Thus, the isovalent substituted $\mathrm{Li}_{2} \mathrm{~V}_{0.5} \mathrm{Ti}_{0.5} \mathrm{O}_{2} \mathrm{~F}$ and $\mathrm{Li}_{2} \mathrm{~V}_{0.5} \mathrm{Fe}_{0.5} \mathrm{O}_{2} \mathrm{~F}$ compounds are synthesized by a high energy ball milling approach and the properties of the compounds are compared with those of $\mathrm{Li}_{2} \mathrm{VO}_{2} \mathrm{~F}$. The structural stability of the materials is investigated by density functional theory (DFT) calculations. Further, we analyze the electrochemical performance by galvanostatic charge-discharge experiments and atomic level information from the material surface is obtained from ex situ hard X-ray photoelectron spectroscopy (HAXPES).

\section{Experimental}

\section{Synthesis procedures}

The compounds were prepared by using a dry ball milling procedure in two steps (each step involves milling at $600 \mathrm{rpm}$ for $20 \mathrm{~h}$ using a Fritsch Pulverisette 6 classic line containing an $80 \mathrm{~mL} \mathrm{Si}_{3} \mathrm{~N}_{4}$ jar and 25 balls of $10 \mathrm{~mm}$ diameter under the conditions of a ball to powder ratio of $10: 1$ and the total amount of powder of approx. $4.5 \mathrm{~g}$ ). All compounds were added into an air-tight $\mathrm{Si}_{3} \mathrm{~N}_{4}$ jar under inert conditions in an argonfilled glovebox with water and oxygen levels below $0.1 \mathrm{ppm}$.

In the first step, $\mathrm{Li}_{2} \mathrm{O}(10 \%$ excess to compensate loss during the synthesis, ${ }^{21}$ Alfa Aesar, 99.7\%) and the corresponding metal oxide precursors, $\mathrm{V}_{2} \mathrm{O}_{3}$ (Alfa Aesar, 99.7\%), and $\mathrm{Ti}_{2} \mathrm{O}_{3}$ (Alfa Aesar, 99.8\%) or $\mathrm{Fe}_{2} \mathrm{O}_{3}$ (Alfa Aesar, 99.9\%), were milled to form the intermediate products DRS $\mathrm{LiVO}_{2}, \mathrm{LiV}_{0.5} \mathrm{Ti}_{0.5} \mathrm{O}_{2}$ or $\mathrm{LiV}_{0.5^{-}}$ $\mathrm{Fe}_{0.5} \mathrm{O}_{2}$, respectively. In the second step LiF (Alfa Aesar, 99.9\%) was added and subsequently milled to stoichiometrically form $\mathrm{Li}_{2} \mathrm{VO}_{2} \mathrm{~F}, \mathrm{Li}_{2} \mathrm{~V}_{0.5} \mathrm{Ti}_{0.5} \mathrm{O}_{2} \mathrm{~F}$ or $\mathrm{Li}_{2} \mathrm{~V}_{0.5} \mathrm{Fe}_{0.5} \mathrm{O}_{2} \mathrm{~F}$, respectively. After ball milling, powders were handled in a glovebox and were used without further purification.

\section{Powder X-ray diffraction (PXRD)}

Synchrotron PXRD patterns were recorded at beamline 11-ID-B at the APS Argonne National Lab using a PerkinElmer flat panel detector (XRD1621) with a pixel size of $200 \times 200 \mu \mathrm{m}$. The powdered samples were placed in $1.1 \mathrm{~mm}$ borosilicate glass capillaries inside an argon-filled glovebox and sealed before they were measured in transmission geometry. A sample-todetector distance of $641.010 \mathrm{~mm}$ and a wavelength of 0.21280 $\AA$ were used for data acquisition with a summed exposure time of $30 \mathrm{~s}$ per diffraction pattern. The diffraction data were integrated using the Fit2D. ${ }^{22-24}$ Rietveld refinements were conducted using TOPAS version $5 .^{25}$ The instrumental resolution function was determined using the $\mathrm{CeO}_{2}$ standard. For the Rietveld refinement, the $b$-factors were refined for the $4 \mathrm{a}$ and $4 \mathrm{~b}$ Wyckoff positions and not for each element individually. The occupancies of $\mathrm{O}$ and $\mathrm{F}$ were fixed to $2 / 3$ for $\mathrm{O}$ and $1 / 3$ for $\mathrm{F}$, respectively. The $\mathrm{TM}$ and $\mathrm{Li}$ occupancies were restrained to result in 1 and refined.

Ex situ PXRD patterns of cycled electrodes after 100 cycles were recorded in reflection geometry using a STOE STADI-p diffractometer with Mo $\mathrm{K}_{\alpha 1}$ radiation (0.70932 $\mathrm{A}$ ), equipped with a DECTRIS MYTHEN 1K strip detector. The electrodes where covered with Kapton ${ }^{\circledR}$ tape to prevent oxidation in air.

\section{Transmission electron microscopy (TEM)}

TEM characterization and energy dispersive X-ray spectroscopy (EDX) mapping were performed using a Cs corrected JEOL ARM CF operating at $200 \mathrm{kV}$, equipped with an SSD Jeol EDX spectrometer.

\section{DFT calculations}

DFT calculations were carried out using the Vienna $A b$ initio Simulation Package (VASP) ${ }^{\mathbf{2 6 - 2 9}}$ using the projector augmentedwave (PAW) method. ${ }^{30}$ The generalized gradient approximation as parametrized by Perdew, Burke and Ernzerhof ${ }^{31}$ was used as the exchange-correlation functional. The plane-wave cutoff of $600 \mathrm{eV}$ was used, and both the cell and atomic positions were fully relaxed such that all the forces are smaller than $0.02 \mathrm{eV}^{-1}$. A rotationally invariant Hubbard $U$ correction $^{32,33}$ was applied to the d orbitals of $\mathrm{V}$, Ti and Fe with the $U$ values of $3.25,3.50$ and $4.30 \mathrm{eV}$, respectively. Integrations over the Brillouin zone were carried out using the Monkhorst-Pack scheme ${ }^{34}$ with a grid with a maximal interval of $0.04 \AA^{-1}$.

\section{Electrochemical measurements}

Electrodes were prepared by pre-mixing $\mathrm{Li}_{2} \mathrm{~V}_{x} \mathrm{TM}_{1-x} \mathrm{O}_{2} \mathrm{~F}(\mathrm{TM}=$ Ti, Fe, $x=1$ or 0.5 ) with carbon black (acetylene black, Alfa Aesar) in the ball mill to form a composite ( $300 \mathrm{rpm}$ for $3 \mathrm{~h}$ ). The obtained composite was mixed with polyvinylidenedifluoride binder (PVDF) (Solvay 6050) and $N$-methyl-2-pyrrolidone (NMP, Alfa Aesar, 99.5\%) solution to obtain a slurry with a weight ratio of $70 / 20 / 10$. The slurry was coated on aluminum foil acting as the current collector and subsequently dried under vacuum at stepwise increasing temperatures up to a maximum of $120{ }^{\circ} \mathrm{C}$ for $12 \mathrm{~h}$. Afterwards electrodes of $12 \mathrm{~mm}$ diameter were 
punched out. The active material mass loading ranges from 1.4 to $1.9 \mathrm{mg} \mathrm{cm}^{-2}$ with a dry film thickness between 12 and $21 \mu \mathrm{m}$.

For the electrochemical measurements, 2-electrode Swagelok-type cells were assembled using a lithium metal counter electrode, $\mathrm{a} \mathrm{Li}_{2} \mathrm{VO}_{2} \mathrm{~F}$ working electrode, $200 \mu \mathrm{L} \mathrm{LP30-}$ electrolyte (1 $\mathrm{M} \mathrm{LiPF}_{6}$ in an ethylene carbonate (EC)/dimethyl carbonate (DMC) mixture (1:1 by volume, Sigma Aldrich)) and two Whatman glass fiber separators. These Li half-cells were assembled in a glovebox under an argon atmosphere. Galvanostatic charge-discharge tests were conducted in the 2electrode setup with an ARBIN BT2000 battery testing system. All electrochemical cycling tests were carried out with a $\mathrm{C} / 5$-rate in a voltage range of $1.3 \mathrm{~V}$ to $4.1 \mathrm{~V} v s$. $\mathrm{Li} / \mathrm{Li}^{+}$. Cycling was performed at room temperature.

\section{HAXPES analysis}

For HAXPES analysis, pouch-type cells were prepared in an argonfilled glovebox $\left(\mathrm{O}_{2}<2 \mathrm{ppm}, \mathrm{H}_{2} \mathrm{O}<1 \mathrm{ppm}\right) .13 \mathrm{~mm}$ diameter electrodes of $\mathrm{Li}_{2} \mathrm{VO}_{2} \mathrm{~F}, \mathrm{Li}_{2} \mathrm{~V}_{0.5} \mathrm{Fe}_{0.5} \mathrm{O}_{2} \mathrm{~F}$ or $\mathrm{Li}_{2} \mathrm{~V}_{0.5} \mathrm{Ti}_{0.5} \mathrm{O}_{2} \mathrm{~F}$ were used as working electrodes with a lithium metal $(125 \mu \mathrm{m}$ thick, Cyprus Foote Material) counter electrode and Solupor separator $(20 \mu \mathrm{m}$ thick) soaked in $50 \mu \mathrm{L}$ LP30-electrolyte. Galvanostatic chargedischarge was performed using a Digatron BTS 600 galvanostat under the same conditions as describe above.

HAXPES was performed on pristine, fully charged and fully discharged electrodes cycled 5 or 50 times. These are abbreviated P, Ch5, DCh5, Ch50, and DCh50 respectively. HAXPES samples were prepared by disassembling the pouch cells, rinsing the working electrode with DMC to remove salt residues, and mounting a piece of the electrode on a sample holder using conductive $\mathrm{Cu}$ or carbon tape. All sample transfers were made under an $\mathrm{Ar}$ atmosphere. For $\mathrm{Li}_{2} \mathrm{VO}_{2} \mathrm{~F}$ and $\mathrm{Li}_{2} \mathrm{~V}_{0.5} \mathrm{Fe}_{0.5} \mathrm{O}_{2} \mathrm{~F}$, measurements were performed at the KMC-1 beamline at BESSY II, Germany ${ }^{35}$ using photon energies of 2005 eV. X-rays were monochromatized using a $\mathrm{Si}(111)$ double-crystal monochromator and a Gammadata Scienta R-4000 hemispherical analyzer was used to record the photoelectron spectra. $\mathrm{Li}_{2} \mathrm{~V}_{0.5} \mathrm{Ti}_{0.5} \mathrm{O}_{2} \mathrm{~F}$ samples were measured at the $\mathrm{I} 09$ beamline at Diamond light source, $\mathrm{UK}^{36}$ using photon energies of $2350 \mathrm{eV}$. X-rays were monochromatized using a Si(111) double-crystal monochromator and a Scienta EW4000 high-voltage electron analyzer was used to record the photoelectron spectra. The probing depth was estimated to be approximately $10 \mathrm{~nm}$ using three times the inelastic mean free path (IMFP) for $\mathrm{Li}_{2} \mathrm{VO}_{2} \mathrm{~F}$ derived from the NIST database ${ }^{37}$ using material parameters from The Materials Project. ${ }^{38}$ HAXPES data analysis and curvefitting were performed using Igor Pro 6.37 software. All spectra were intensity normalized to the highest intensity peak and binding energy calibrated by shifting the carbon black peak to $284.4 \mathrm{eV}$. To curve fit the transition metal spectra, the spin orbit splitting of the $2 \mathrm{p}_{3 / 2}$ and $2 \mathrm{p}_{1 / 2}$ doublet peaks was locked to established values (7.3 eV for V, $5.7 \mathrm{eV}$ for $\mathrm{Ti}$, and 13.6 for $\mathrm{Fe}$ ) while the absolute binding energy values were allowed to vary. In the case of vanadium, only one spin orbit split doublet peak was used to fit the spectra, and its binding energy was used to determine the oxidation state. For $\mathrm{V} 2 \mathrm{p}$ and $\mathrm{Ti} 2 \mathrm{p}$ peaks, parameters from the work by Biesinger et $a l .{ }^{39}$ were used for the fitting. The Fe 2p peaks partially overlap with the plasmon of the $\mathrm{F}$ 1s peak. ${ }^{40}$ By comparing the survey measurements of $\mathrm{Li}_{2} \mathrm{~V}_{0.5} \mathrm{Fe}_{0.5} \mathrm{O}_{2} \mathrm{~F}$ and $\mathrm{Li}_{2} \mathrm{VO}_{2} \mathrm{~F}$ (ESI, Fig. S11 $\dagger$ ) it was determined that the Fe $2 \mathrm{p}_{1 / 2}$ peak lies above the fluorine plasmon and can thus be used to evaluate iron. The Fe $2 p_{1 / 2}$ was fitted using established peak parameters. ${ }^{\mathbf{4 1 , 4 2}}$ Further details on the fitting can be found in the ESI. $\dagger$ To evaluate the composition of the samples, peak areas are calculated and normalized by the photoionization cross section. Ratios between different elements are calculated according to eqn (1):

$$
\frac{n_{i}}{n_{j}}=\frac{A_{i} / \sigma_{i}}{A_{j} / \sigma_{j}}
$$

where $A_{i, j}$ is the peak area of elements $i$ and $j$ and $\sigma_{i, j}$ is the theoretical absorption cross section of the corresponding elements as calculated according to the work by Scofield. ${ }^{43}$

\section{Results}

We synthesized the target compounds $\mathrm{Li}_{2} \mathrm{~V}_{0.5} \mathrm{Ti}_{0.5} \mathrm{O}_{2} \mathrm{~F}$ and $\mathrm{Li}_{2} \mathrm{~V}_{0.5} \mathrm{Fe}_{0.5} \mathrm{O}_{2} \mathrm{~F}$ by a high energy ball milling approach, similar to the reported synthesis of $\mathrm{Li}_{2} \mathrm{VO}_{2} \mathrm{~F}$. ${ }^{5}$ High energy ball milling is often used to synthesize metastable phases or to stabilize phases that normally exist at higher temperatures or pressures. ${ }^{\mathbf{4 4}}$ The synthesis procedures reported in the literature so far synthesize the DRS compounds in a one-step process, which in some cases leads to impurities of unreacted precursor compounds. ${ }^{5,15}$ In the case of $\mathrm{Li}_{2} \mathrm{VO}_{2} \mathrm{~F}$, a total ball milling time of 40 hours is suggested. ${ }^{5}$ Here, we introduce a two-step approach. In the first step, we synthesized a $\mathrm{LiTMO}_{2}$ species by using $\mathrm{Li}_{2} \mathrm{O}$ and the corresponding $\mathrm{TM}_{2} \mathrm{O}_{3}$ oxide already exhibits the DRS structure. ${ }^{45}$ In a second step, LiF was introduced into the structure as a solid solution by ball milling. This approach has the advantage of significantly reducing the transition metal oxide precursor impurities in the product. Additionally, we changed the ball mill jar and ball material from tungsten carbide (WC) to less abrasive silicon nitride $\left(\mathrm{Si}_{3} \mathrm{~N}_{4}\right)$, which reduces the amount of impurities in the synthesized compound. Following this approach, we successfully synthesized two new Li-rich DRS materials, $\mathrm{Li}_{2} \mathrm{~V}_{0.5} \mathrm{Ti}_{0.5} \mathrm{O}_{2} \mathrm{~F}$ and $\mathrm{Li}_{2} \mathrm{~V}_{0.5} \mathrm{Fe}_{0.5} \mathrm{O}_{2} \mathrm{~F}$, and compared them with the original $\mathrm{Li}_{2} \mathrm{VO}_{2} \mathrm{~F}$ compound.

Rietveld refinements based on the synchrotron PXRD of $\mathrm{Li}_{2} \mathrm{~V}_{0.5} \mathrm{Ti}_{0.5} \mathrm{O}_{2} \mathrm{~F}$ and $\mathrm{Li}_{2} \mathrm{~V}_{0.5} \mathrm{Fe}_{0.5} \mathrm{O}_{2} \mathrm{~F}$, both mixed with carbon black, are presented in Fig. 1. The broad diffraction peaks of both compounds indicate the nanocrystalline nature of the material, as known for $\mathrm{Li}_{2} \mathrm{VO}_{2} \mathrm{~F}$ (ESI, Fig. S2 $\dagger$ ) and similar ball milled materials. ${ }^{\mathbf{5 , 9 , 1 5 , 2 1 , 4 5}}$ Rietveld refinements are based on the DRS phase $(F m \overline{3} m)$ for both $\mathrm{Li}_{2} \mathrm{~V}_{0.5} \mathrm{Ti}_{0.5} \mathrm{O}_{2} \mathrm{~F}$ and $\mathrm{Li}_{2} \mathrm{~V}_{0.5} \mathrm{Fe}_{0.5} \mathrm{O}_{2} \mathrm{~F}$ and yield in good fits. The Rietveld refinements show that the synthesized products have high purity (the products contain below $1 \mathrm{wt} \%$ of $\mathrm{Si}_{3} \mathrm{~N}_{4}$ impurity). No transition metal precursors $\left(\mathrm{TM}_{2} \mathrm{O}_{3}\right)$ were found. The refinements yield lattice parameters of $a=4.1342(6) \AA$ for $\mathrm{Li}_{2} \mathrm{~V}_{0.5} \mathrm{Ti}_{0.5} \mathrm{O}_{2} \mathrm{~F}$ and $a=4.1388(6) \AA$ for $\mathrm{Li}_{2} \mathrm{~V}_{0.5} \mathrm{Fe}_{0.5} \mathrm{O}_{2} \mathrm{~F}$, which are slightly larger compared to that of the unsubstituted compound $\mathrm{Li}_{2} \mathrm{VO}_{2} \mathrm{~F}(a=4.1169(4) \AA)$ due to the 


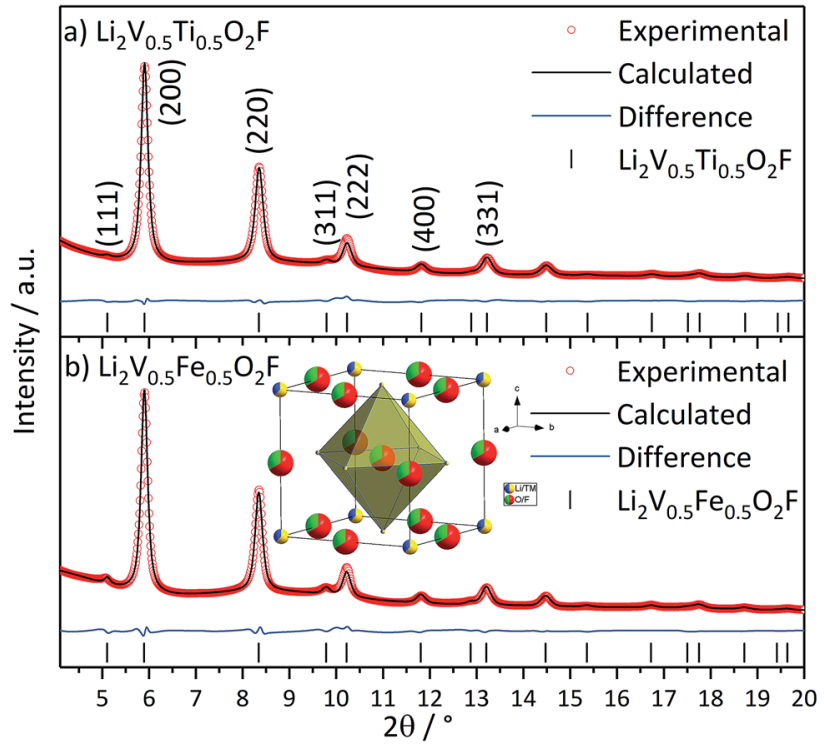

Fig. 1 (a) PXRD pattern of $\mathrm{Li}_{2} \mathrm{~V}_{0.5} \mathrm{Ti}_{0.5} \mathrm{O}_{2} \mathrm{~F}$ mixed with carbon black with Rietveld refinement and the Bragg position of $\mathrm{Li}_{2} \mathrm{~V}_{0.5} \mathrm{Ti}_{0.5} \mathrm{O}_{2} \mathrm{~F}$. (b) PXRD pattern of $\mathrm{Li}_{2} \mathrm{~V}_{0.5} \mathrm{Fe}_{0.5} \mathrm{O}_{2} \mathrm{~F}$ mixed with carbon black with Rietveld refinement and the Bragg position of $\mathrm{Li}_{2} \mathrm{~V}_{0.5} \mathrm{Fe}_{0.5} \mathrm{O}_{2} \mathrm{~F} . \lambda=0.21280 \AA$. Inset: schematic illustration of the DRS crystal structure.

larger ionic radii of $\mathrm{Ti}^{3+}$ and $\mathrm{Fe}^{3+} \cdot{ }^{46}$ The refined occupancies of the transition metal positions differ only marginally from the ideal stoichiometry for the $\mathrm{Ti}$ and $\mathrm{Fe}$ containing phases. Detailed structural parameters obtained from the refinement are given in ESI Table S1. $\uparrow$ The crystallite size (between 12 and $14 \mathrm{~nm}$ ) and strain (below 0.6\%) were determined from Williamson-Hall plots (ESI, Fig. S3†). ${ }^{47}$

The particle size and morphology of $\mathrm{Li}_{2} \mathrm{~V}_{0.5} \mathrm{Ti}_{0.5} \mathrm{O}_{2} \mathrm{~F}$, $\mathrm{Li}_{2} \mathrm{~V}_{0.5} \mathrm{Fe}_{0.5} \mathrm{O}_{2} \mathrm{~F}$ and $\mathrm{Li}_{2} \mathrm{VO}_{2} \mathrm{~F}$ were investigated by TEM. The results for $\mathrm{Li}_{2} \mathrm{~V}_{0.5} \mathrm{Ti}_{0.5} \mathrm{O}_{2} \mathrm{~F}$ are presented in Fig. 2. The results for $\mathrm{Li}_{2} \mathrm{~V}_{0.5} \mathrm{Fe}_{0.5} \mathrm{O}_{2} \mathrm{~F}$ and $\mathrm{Li}_{2} \mathrm{VO}_{2} \mathrm{~F}$ are given in the ESI (ESI, Fig. S4-S6†). The sample is composed of agglomerated nanocrystalline particles (Fig. 2a). Similar microstructures have been found for $\mathrm{Li}_{2} \mathrm{~V}_{0.5} \mathrm{Fe}_{0.5} \mathrm{O}_{2} \mathrm{~F}$ and $\mathrm{Li}_{2} \mathrm{VO}_{2} \mathrm{~F}$. The lattice $d$-values obtained by selected area electron diffraction (SAED) (Fig. 2b) correspond to the metrics of the DRS structure $(F m \overline{3} m)$ and confirm the results of the Rietveld refinement. The highresolution scanning transmission electron microscopy annular dark field image (STEM-ADF) in Fig. 2c reveals several nanocrystalline (5-10 $\mathrm{nm})$ and some amorphous domains. The corresponding fast Fourier transformation (FFT) of one nanocrystallite is shown in Fig. 2d, matching the orientation along the [101] zone axis of the disordered structure. Despite the local non-uniform mass-thickness contrast in the image, it is possible to identify some differences in the intensity of the atomic columns, indicating variations of the transition metal atomic content. Similar results have been obtained for $\mathrm{Li}_{2} \mathrm{VO}_{2} \mathrm{~F}$ and $\mathrm{Li}_{2} \mathrm{~V}_{0.5} \mathrm{Fe}_{0.5} \mathrm{O}_{2} \mathrm{~F}$. Energy dispersive $\mathrm{X}$-ray spectroscopy mapping (EDX) of the materials shows a uniform distribution of elements. However, in the case of $\mathrm{Li}_{2} \mathrm{~V}_{0.5} \mathrm{Fe}_{0.5} \mathrm{O}_{2} \mathrm{~F}$ the EDX map reveals a small fraction of V-enriched areas of $40-80 \mathrm{~nm}$ size,
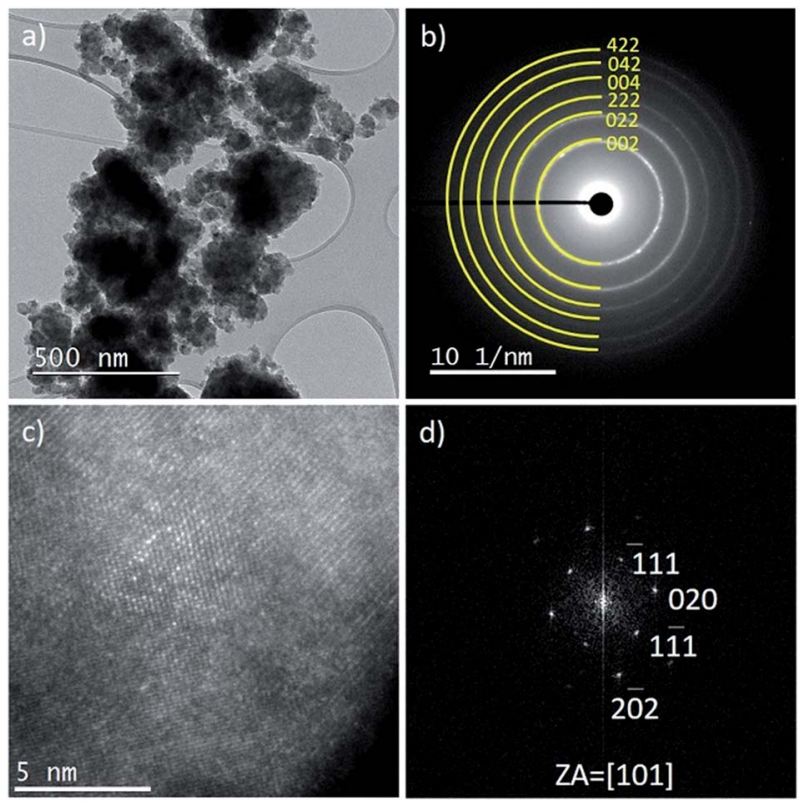

Fig. 2 TEM analysis of $\mathrm{Li}_{2} \mathrm{~V}_{0.5} \mathrm{Ti}_{0.5} \mathrm{O}_{2} \mathrm{~F}$. (a) TEM image, (b) SAED pattern, and (c) high-resolution STEM ADF image with corresponding FFT (d).

which are not present in the X-ray diffraction pattern (ESI, Fig. S6†).

To shed light on the structural properties of $\mathrm{Li}_{2} \mathrm{VO}_{2} \mathrm{~F}$, $\mathrm{Li}_{2} \mathrm{~V}_{0.5} \mathrm{Ti}_{0.5} \mathrm{O}_{2} \mathrm{~F}$ and $\mathrm{Li}_{2} \mathrm{~V}_{0.5} \mathrm{Fe}_{0.5} \mathrm{O}_{2} \mathrm{~F}$ we investigated the relative structural stability of DRS oxyfluoride phases using DFT calculations by comparing the energies of Special Quasi-random Structures (SQS) and ordered prototype structures. These are derived from known ordered oxide structures such as $\alpha-\mathrm{NaFeO}_{2}$ and $\gamma-\mathrm{LiFeO}_{2}$, which are known to be the ground state structure of many lithium transition metal oxides (ESI, Fig. S7 and S8 $\dagger){ }^{48,49}$ The relative structural stability of DRS oxyfluoride phases is determined via the energy difference between the SQS and the most stable ordered structure, $\Delta E$, defined as

$$
\Delta E=E_{\mathrm{SQS}}-\min \left(E_{\text {ordered }}\right)
$$

where $E_{\mathrm{SQS}}$ and $\min \left(E_{\text {ordered }}\right)$ are the total energies of SQS and the most stable ordered structure in meV per atom, respectively. A positive (negative) value of $\Delta E$ indicates that the disordered phase is energetically less (more) stable compared to an ordered phase.

The ordered phase is expected to be more structurally stable than the disordered phase for all considered compounds, because the DRS oxyfluorides are in the metastable phase achieved using a mechanochemical ball milling procedure. Furthermore, the decomposition of $\mathrm{Li}_{2} \mathrm{VO}_{2} \mathrm{~F}$ into $\mathrm{LiVO}_{2}$ and $\mathrm{LiF}$ upon heating ${ }^{50}$ indicates that the considered compounds may be metastable in general, irrespective of the ordered or disordered phase. Such metastability of the compounds makes it difficult to investigate their relative structural stabilities. However, the ordering propensity, the extent to which the ordered phase is preferred compared to the disordered phase, can be used to assess the relative stability of the compared DRS 
oxyfluoride compounds. ${ }^{49}$ In other words, the relative values of $\Delta E$ in eqn (2) are used to assess how stable the compounds are in the disordered phase compared to the ordered phase. The value of $\Delta E$ is 179,144 and $147 \mathrm{meV}$ per atom for $\mathrm{Li}_{2} \mathrm{VO}_{2} \mathrm{~F}$, $\mathrm{Li}_{2} \mathrm{~V}_{0.5} \mathrm{Ti}_{0.5} \mathrm{O}_{2} \mathrm{~F}$ and $\mathrm{Li}_{2} \mathrm{~V}_{0.5} \mathrm{Fe}_{0.5} \mathrm{O}_{2} \mathrm{~F}$, respectively. The ordered phase is energetically preferred for all three compounds, and the disordered phase is metastable as expected. More interestingly, the $\Delta E$ values of $\mathrm{Li}_{2} \mathrm{~V}_{0.5} \mathrm{Ti}_{0.5} \mathrm{O}_{2} \mathrm{~F}$ and $\mathrm{Li}_{2} \mathrm{~V}_{0.5} \mathrm{Fe}_{0.5} \mathrm{O}_{2} \mathrm{~F}$ are lower than those of $\mathrm{Li}_{2} \mathrm{VO}_{2} \mathrm{~F}$ by more than $30 \mathrm{meV}$ per atom, indicating enhanced structural stability of the disordered phase. Consequently, $\mathrm{Li}_{2} \mathrm{~V}_{0.5} \mathrm{Ti}_{0.5} \mathrm{O}_{2} \mathrm{~F}$ and $\mathrm{Li}_{2} \mathrm{~V}_{0.5} \mathrm{Fe}_{0.5} \mathrm{O}_{2} \mathrm{~F}$ are more likely to retain the disordered phase upon cycling than $\mathrm{Li}_{2} \mathrm{VO}_{2} \mathrm{~F}$. It should be noted that the relative energies of the decomposed products of the compounds $\left(\mathrm{LiF}+\mathrm{LiTMO}_{2}\right.$ for $\mathrm{Li}_{2} \mathrm{TMO}_{2} \mathrm{~F}$ and $\mathrm{LiF}+0.5 \mathrm{LiTM}_{2} \mathrm{O}_{2}+0.5 \mathrm{LiTM} 2 \mathrm{O}_{2}$ for $\mathrm{Li}_{2} \mathrm{TM} 1_{0.5} \mathrm{TM} 2_{0.5} \mathrm{O}_{2} \mathrm{~F}$, where more stable $\alpha-\mathrm{NaFeO}_{2}$ and $\gamma-\mathrm{LiFeO}_{2}$ type oxide structures are considered) are also compared (ESI, Table S2 $\dagger$ ). All of the compounds are found to be most stable in the decomposed state, which aligns with the challenges faced in synthesizing the compounds in conventional techniques.

In addition to the relative stabilities of the disordered and ordered phases, DFT calculations reveal that the disorder leads to a distribution of oxidation states of the transition metal ions in the compounds. The oxidation states of $\mathrm{TM}$ in $\mathrm{Li}_{2} \mathrm{TMO}_{2} \mathrm{~F}$ and TM1 and TM2 in $\mathrm{Li}_{2} \mathrm{TM}_{0.5} \mathrm{TM} 2_{0.5} \mathrm{O}_{2} \mathrm{~F}$ (TM, TM1 and TM2 = V, $\mathrm{Ti}, \mathrm{Fe}$, respectively) are always $3+$ for all of the ordered structures. The oxidation states of $\mathrm{V}$ ions are distributed between $2+$, $3+$ and $4+$ in the SQS of $\mathrm{Li}_{2} \mathrm{TMO}_{2} \mathrm{~F}$ (the distribution of oxidation states of the transition metals of the SQS is shown in Table S3 of ESI $\dagger$ ). Furthermore, it is observed that the substitution of $\mathrm{V}$ with Ti leads to a downward shift in the oxidation state distribution of $\mathrm{V}$ ions (between $2+$ and $3+$ ) while Ti ions have oxidation states of $3+$ and $4+$. The opposite happens when $\mathrm{V}$ ions are substituted with Fe ions; oxidation states of $\mathrm{V}$ ions are distributed between $3+$ and $4+$ while they are distributed between $2+$ and $3+$ for Fe ions. A constant value of oxidation states in the ordered phase and its distribution pattern in the disordered phase can be used to determine the extent to which the material is disordered, albeit to a first order approximation.

The electrochemical performance of the new DRS oxyfluoride compounds $\mathrm{Li}_{2} \mathrm{~V}_{0.5} \mathrm{Ti}_{0.5} \mathrm{O}_{2} \mathrm{~F}$ and $\mathrm{Li}_{2} \mathrm{~V}_{0.5} \mathrm{Fe}_{0.5} \mathrm{O}_{2} \mathrm{~F}$ was investigated. The proposed theoretical capacity of $\mathrm{Li}_{2} \mathrm{VO}_{2} \mathrm{~F}$ is $462 \mathrm{~mA} \mathrm{~h} \mathrm{~g}{ }^{-1}$ based on a $2 \mathrm{e}^{-}$redox process of the $\mathrm{V}^{3+} / \mathrm{V}^{5+}$ couple. $\mathrm{Li}_{2} \mathrm{~V}_{0.5} \mathrm{Ti}_{0.5} \mathrm{O}_{2} \mathrm{~F}$ has a theoretical capacity of $350 \mathrm{~mA} \mathrm{~h} \mathrm{~g}{ }^{-1}$ based on a $1.5 \mathrm{e}^{-}$redox process assuming additional redox activity of $\mathrm{Ti}^{3+} / \mathrm{Ti}^{4+}$ in the low voltage range between 1.5 and $2.0 \mathrm{~V}^{51} \mathrm{Li}_{2} \mathrm{~V}_{0.5} \mathrm{Fe}_{0.5} \mathrm{O}_{2} \mathrm{~F}$ has a theoretical capacity of $226 \mathrm{~mA} \mathrm{~h} \mathrm{~g}^{-1}$ assuming electrochemical inactivity of $\mathrm{Fe}^{3+}\left(2 \mathrm{e}^{-}\right.$ redox process of $50 \% \mathrm{~V}^{3+} / \mathrm{V}^{5+}$ ). Galvanostatic charge-discharge tests of $\mathrm{Li}_{2} \mathrm{VO}_{2} \mathrm{~F}, \mathrm{Li}_{2} \mathrm{~V}_{0.5} \mathrm{Ti}_{0.5} \mathrm{O}_{2} \mathrm{~F}$ and $\mathrm{Li}_{2} \mathrm{~V}_{0.5} \mathrm{Fe}_{0.5} \mathrm{O}_{2} \mathrm{~F}$ half cells have been conducted. The cycling performance is shown in Fig. 3. The materials have been cycled within a potential range of 1.3 and $4.1 \mathrm{~V}$ vs. $\mathrm{Li} / \mathrm{Li}^{+}$with a $\mathrm{C} / 5$-rate. $\mathrm{Li}_{2} \mathrm{VO}_{2} \mathrm{~F}$ shows the highest first discharge capacity of all three compounds (Fig. 3a) of around $330 \mathrm{~mA} \mathrm{~h} \mathrm{~g}{ }^{-1}$, which is in good agreement with the literature, accompanied by rapid capacity fading known from previous reports. ${ }^{5,14} 45 \%$ of the initial discharge capacity is lost
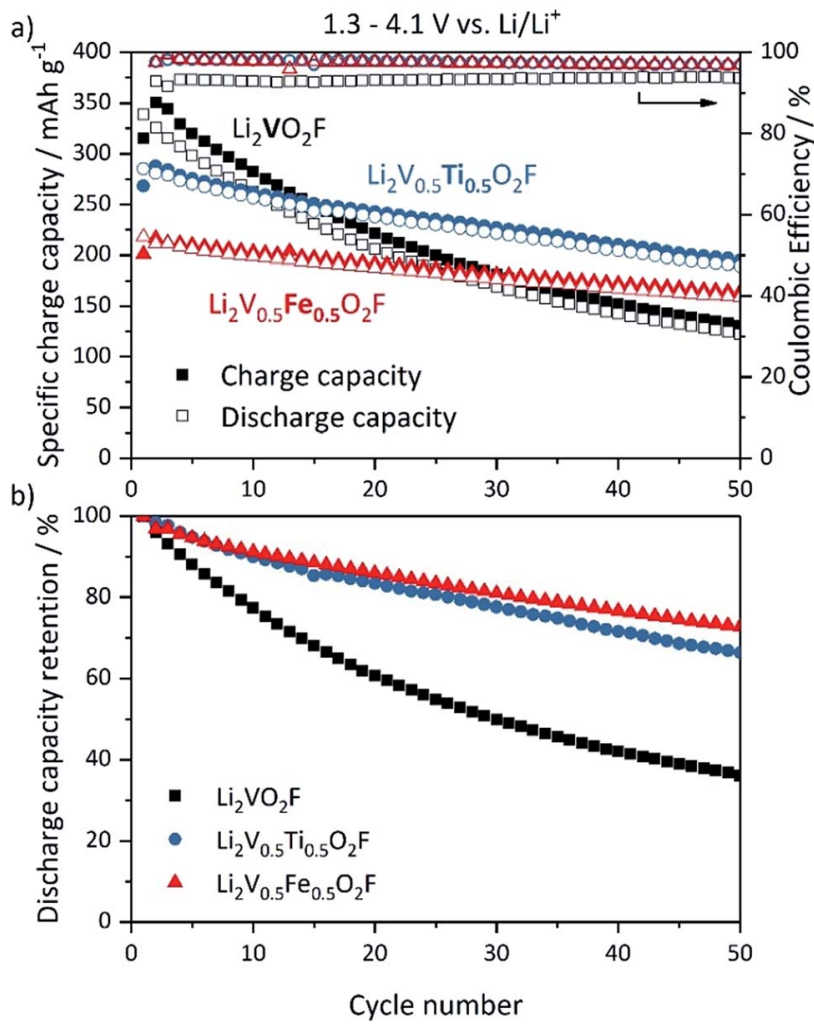

Fig. 3 (a) Cycling performance (filled symbols: charge capacity, hollow symbols: discharge capacity) and coulombic efficiency of $\mathrm{Li}_{2} \mathrm{VO}_{2} \mathrm{~F}$ (black), $\mathrm{Li}_{2} \mathrm{~V}_{0.5} \mathrm{Ti}_{0.5} \mathrm{O}_{2} \mathrm{~F}$ (blue) and $\mathrm{Li}_{2} \mathrm{~V}_{0.5} \mathrm{Fe}_{0.5} \mathrm{O}_{2} \mathrm{~F}$ (red) as a function of cycle number for half-cells cycled within a potential range of $1.3-4.1 \mathrm{~V}$ vs. $\mathrm{Li} / \mathrm{Li}^{+}$with $\mathrm{C} / 5$-rate at $25^{\circ} \mathrm{C}$. (b) Corresponding discharge capacity retention of the compounds.

after 25 cycles. After 50 cycles the discharge capacity is already below $150 \mathrm{~mA} \mathrm{~h} \mathrm{~g}^{-1}$, which corresponds to less than $40 \%$ capacity retention (Fig. 3b). Both substituted compounds, $\mathrm{Li}_{2} \mathrm{~V}_{0.5} \mathrm{Ti}_{0.5} \mathrm{O}_{2} \mathrm{~F}$ and $\mathrm{Li}_{2} \mathrm{~V}_{0.5} \mathrm{Fe}_{0.5} \mathrm{O}_{2} \mathrm{~F}$, exhibit a lower discharge capacity of $285 \mathrm{~mA} \mathrm{~h} \mathrm{~g}^{-1}$ and $218 \mathrm{~mA} \mathrm{~h} \mathrm{~g}^{-1}$ in the first cycle, respectively. The discharge capacity of $\mathrm{Li}_{2} \mathrm{~V}_{0.5} \mathrm{Ti}_{0.5} \mathrm{O}_{2} \mathrm{~F}$ is $67 \mathrm{~mA} \mathrm{~h} \mathrm{~g}^{-1}$ higher compared to $\mathrm{Li}_{2} \mathrm{~V}_{0.5} \mathrm{Fe}_{0.5} \mathrm{O}_{2} \mathrm{~F}$, which may be explained by additional contribution to the capacity of the $\mathrm{Ti}^{3+} / \mathrm{Ti}^{4+}$ redox couple. The capacity fading is significantly reduced for both substituted compounds; $\mathrm{Li}_{2} \mathrm{~V}_{0.5} \mathrm{Ti}_{0.5} \mathrm{O}_{2} \mathrm{~F}$ and $\mathrm{Li}_{2} \mathrm{~V}_{0.5} \mathrm{Fe}_{0.5} \mathrm{O}_{2} \mathrm{~F}$ retain $81 \%$ and $83 \%$ of the initial discharge capacity after 25 cycles and $66 \%$ and $73 \%$ after 50 cycles, respectively. The coulombic efficiency (Fig. 3a) is improved for both new materials (around 97\% for 50 cycles) compared to $\mathrm{Li}_{2} \mathrm{VO}_{2} \mathrm{~F}$ (around 93\%). Altogether, the substitution of $\mathrm{V}$ with $50 \% \mathrm{Ti}$ or $\mathrm{Fe}$ clearly improves the cycling performance compared to $\mathrm{Li}_{2} \mathrm{VO}_{2} \mathrm{~F}$. $\mathrm{Li}_{2} \mathrm{~V}_{0.5} \mathrm{Fe}_{0.5} \mathrm{O}_{2} \mathrm{~F}$ shows the best cycling stability over 50 cycles, whereas $\mathrm{Li}_{2} \mathrm{~V}_{0.5} \mathrm{Ti}_{0.5} \mathrm{O}_{2} \mathrm{~F}$ exhibits the highest overall discharge capacities. The corresponding voltage profiles of $\mathrm{Li}_{2} \mathrm{VO}_{2} \mathrm{~F}, \mathrm{Li}_{2} \mathrm{~V}_{0.5} \mathrm{Ti}_{0.5} \mathrm{O}_{2} \mathrm{~F}$ and $\mathrm{Li}_{2} \mathrm{~V}_{0.5} \mathrm{Fe}_{0.5} \mathrm{O}_{2} \mathrm{~F}$ exhibit a steep and sloping profile shape enhanced by the disorder suggesting a single-phase insertion process for $\mathrm{Li}^{+}$(ESI, Fig. S9†). ${ }^{\mathbf{5}, \mathbf{1 4}}$ No voltage plateaus are observed. The average discharge voltage of $\mathrm{Li}_{2} \mathrm{VO}_{2} \mathrm{~F}$ is about $2.53 \mathrm{~V}$ with a voltage 
hysteresis of $0.51 \mathrm{~V}$. Both substituted compounds exhibit a slightly lower average discharge voltage, $2.31 \mathrm{~V}$ for $\mathrm{Li}_{2} \mathrm{~V}_{0.5} \mathrm{Ti}_{0.5} \mathrm{O}_{2} \mathrm{~F}$ and $2.45 \mathrm{~V}$ for $\mathrm{Li}_{2} \mathrm{~V}_{0.5} \mathrm{Fe}_{0.5} \mathrm{O}_{2} \mathrm{~F}$. The voltage hysteresis for $\mathrm{Li}_{2} \mathrm{~V}_{0.5} \mathrm{Ti}_{0.5} \mathrm{O}_{2} \mathrm{~F}$ is $0.59 \mathrm{~V}$, which is the highest of all three compounds. $\mathrm{Li}_{2} \mathrm{~V}_{0.5} \mathrm{Fe}_{0.5} \mathrm{O}_{2} \mathrm{~F}$ shows the smallest voltage hysteresis of $0.43 \mathrm{~V}$.

To understand the redox processes occurring during electrochemical cycling the differential capacity $\mathrm{d} Q / \mathrm{d} V$ plots are shown in Fig. 4. In $\mathrm{Li}_{2} \mathrm{VO}_{2} \mathrm{~F}$, the oxidation of $\mathrm{V}^{3+}$ to $\mathrm{V}^{4+}$ is located in the area of $2.6 \mathrm{~V}$ and that of $\mathrm{V}^{4+}$ to $\mathrm{V}^{5+}$ is located above $3.5 \mathrm{~V}$ (indicated with dashed lines). ${ }^{\mathbf{1 4 , 1 5}}$ For $\mathrm{Li}_{2} \mathrm{~V}_{0.5} \mathrm{Ti}_{0.5} \mathrm{O}_{2} \mathrm{~F}$, the assumed redox peaks of vanadium (dashed lines) are slightly shifted to higher voltages and exhibit the highest overpotentials, which may be related to kinetic effects. Furthermore, additional peaks in the charge and discharge directions are observed at $2.2 \mathrm{~V}$ and $1.8 \mathrm{~V}$, respectively (dotted lines). These peaks are not present in the samples that do not contain $\mathrm{Ti}$ $\left(\mathrm{Li}_{2} \mathrm{VO}_{2} \mathrm{~F}\right.$ and $\left.\mathrm{Li}_{2} \mathrm{~V}_{0.5} \mathrm{Fe}_{0.5} \mathrm{O}_{2} \mathrm{~F}\right)$ and thus are expected to originate from the $\mathrm{Ti}^{3+} / \mathrm{Ti}^{4+}$ redox couple leading to an additional discharge capacity. $\mathrm{Li}_{2} \mathrm{~V}_{0.5} \mathrm{Fe}_{0.5} \mathrm{O}_{2} \mathrm{~F}$ shows the smallest overpotential and behaves like $\mathrm{Li}_{2} \mathrm{VO}_{2} \mathrm{~F}$ in the low voltage regime indicating a similar redox behavior, but differs in the voltage region above $3.5 \mathrm{~V}$ during charging. This deviation may be related to processes at high voltages associated with irreversible reactions affecting the cycling stability. Upon extended cycling

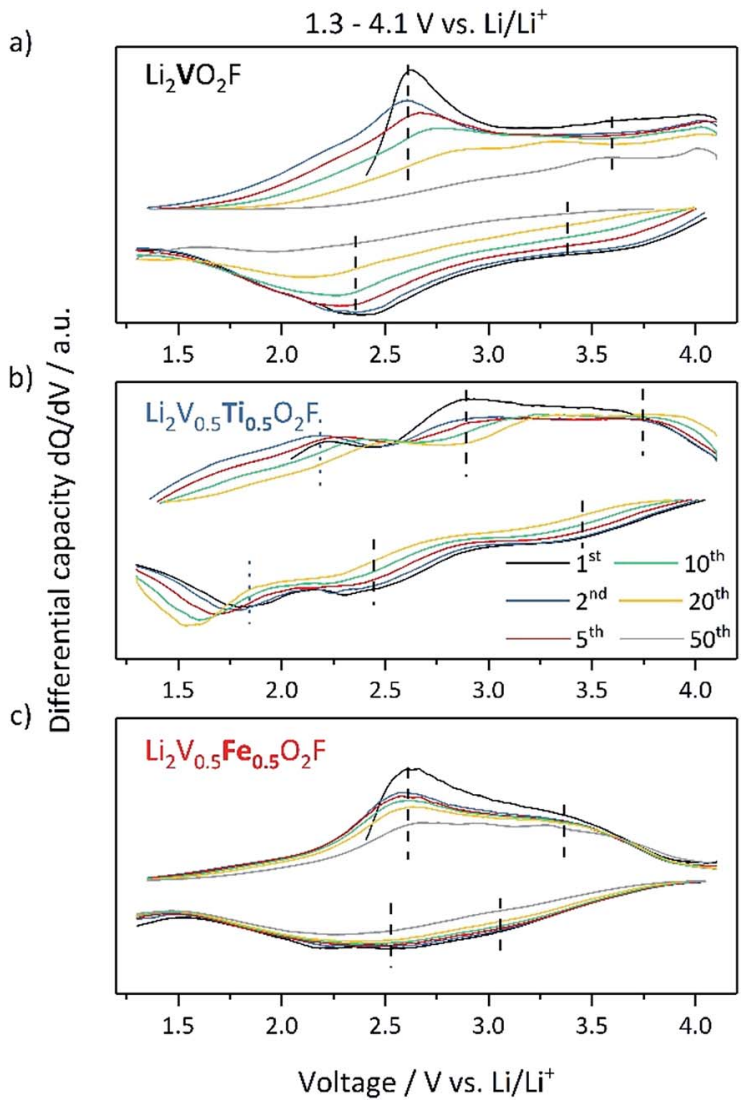

Fig. 4 Differential capacity curves of (a) $\mathrm{Li}_{2} \mathrm{VO}_{2} \mathrm{~F}$, (b) $\mathrm{Li}_{2} \mathrm{~V}_{0.5} \mathrm{Ti}_{0.5} \mathrm{O}_{2} \mathrm{~F}$ and (c) $\mathrm{Li}_{2} \mathrm{~V}_{0.5} \mathrm{Fe}_{0.5} \mathrm{O}_{2} \mathrm{~F}$ half-cells cycled within a potential range of 1.3-4.1 V vs. Li/Li ${ }^{+}$with $\mathrm{C} / 5$-rate at $25^{\circ} \mathrm{C}$. the $\mathrm{d} Q / \mathrm{d} V$ plot of $\mathrm{Li}_{2} \mathrm{VO}_{2} \mathrm{~F}$ tends to a flattening differential capacity peak response, indicating a loss of V-redox activity. ${ }^{20} \mathrm{In}$ contrast, $\mathrm{Li}_{2} \mathrm{~V}_{0.5} \mathrm{Ti}_{0.5} \mathrm{O}_{2} \mathrm{~F}$ and $\mathrm{Li}_{2} \mathrm{~V}_{0.5} \mathrm{Fe}_{0.5} \mathrm{O}_{2} \mathrm{~F}$ preserve the characteristic redox peaks for a longer cycling period. This suggests that the maintained electrochemical activity of the TM is related to the improved cycling stability of the materials. Like for $\mathrm{Li}_{2} \mathrm{VO}_{2} \mathrm{~F}$, the ex situ PXRD pattern of $\mathrm{Li}_{2} \mathrm{~V}_{0.5} \mathrm{Ti}_{0.5} \mathrm{O}_{2} \mathrm{~F}$ and $\mathrm{Li}_{2} \mathrm{~V}_{0.5} \mathrm{Fe}_{0.5} \mathrm{O}_{2} \mathrm{~F}$ after extended cycling does not exhibit any development of new crystalline phases (ESI, Fig. S10 $\dagger$ ). ${ }^{5}$

To further analyze the materials' surface stability, HAXPES was used to probe the redox activity of the transition metals and the surface layer evolution. Since HAXPES is a surface sensitive technique it has commonly been used to study the surface layers built up on the active material, known to be crucial for the cycling performance. ${ }^{52,53}$ Thus, to understand the improved capacity retention of the substituted materials the $\mathrm{O} 1 \mathrm{~s}, \mathrm{~V} 2 \mathrm{p}$ and $\mathrm{C} 1 \mathrm{~s}$ spectra are analyzed for pristine $(\mathrm{P})$ and samples cycled 5 or 50 times in both charged (Ch5 and Ch50, respectively) and discharged (DCh5 and DCh50, respectively) states. The photon energy for the measurements is chosen so that both the outer layers of the active material and the surface layer can be probed.

The $\mathrm{O} 1 \mathrm{~s}$ and V 2p spectra are shown in Fig. 5. Five different peaks are used to fit the data, from left to right corresponding to carboxyl/hydroxyl compounds ( $\sim 534 \mathrm{eV})$, carbonates $(\sim 532 \mathrm{eV})$, metal oxide $(530 \mathrm{eV})$ and vanadium that is detected with a spin orbit splitting of $7.33 \mathrm{eV}$ at $\sim 517$ and $524 \mathrm{eV}$ according to peak parameters summarized by Biesinger et $a .^{39}$ The energy difference of the $\mathrm{O} 1 \mathrm{~s}$ metal oxide peak and $\mathrm{V} 2 \mathrm{p}_{3 / 2}$ can be used to determine the oxidation state of $\mathrm{V}$, where a larger value corresponds to a lower oxidation state. The values obtained from the fitting are presented in Table 1. The pristine samples show differences in the average vanadium oxidation state depending on the material. $\mathrm{Li}_{2} \mathrm{VO}_{2} \mathrm{~F}$ and $\mathrm{Li}_{2} \mathrm{~V}_{0.5} \mathrm{Ti}_{0.5} \mathrm{O}_{2} \mathrm{~F}$ show vanadium in a mix of $\mathrm{V}^{3+}$ and $\mathrm{V}^{4+}$, while $\mathrm{Li}_{2} \mathrm{~V}_{0.5} \mathrm{Fe}_{0.5} \mathrm{O}_{2} \mathrm{~F}$ contains a mix of $\mathrm{V}^{4+}$
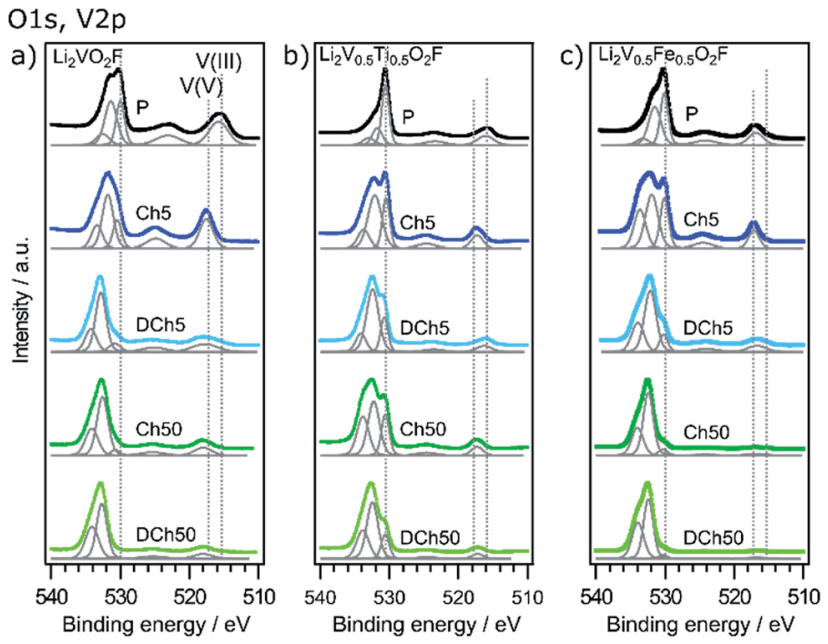

Fig. $5 \bigcirc 1 \mathrm{~s}$ and $\mathrm{V} 2 \mathrm{p}$ photoelectron spectra of the three different materials in pristine, charged and discharged states after 5 and 50 cycles, obtained using a photon energy of $2005 \mathrm{eV}$ ( $a$ and c) or $2350 \mathrm{eV}$ (b). Dotted lines indicate reference values for metal oxide $\left(530 \mathrm{eV}\right.$ ) and different oxidation states of vanadium. ${ }^{39}$ 
Table 1 Binding energy difference $(\triangle \mathrm{BE})$ between the metal oxide and $V 2 p_{3 / 2}$ peak and FWHM for the $V 2 p_{3 / 2}$ peak for different samples ${ }^{a}$

\begin{tabular}{|c|c|c|c|c|c|c|}
\hline \multirow[b]{2}{*}{ Material } & \multicolumn{2}{|c|}{$\mathrm{Li}_{2} \mathrm{VO}_{2} \mathrm{~F}$} & \multicolumn{2}{|c|}{$\mathrm{Li}_{2} \mathrm{~V}_{0.5} \mathrm{Ti}_{0.5} \mathrm{O}_{2} \mathrm{~F}$} & \multicolumn{2}{|c|}{$\mathrm{Li}_{2} \mathrm{~V}_{0.5} \mathrm{Fe}_{0.5} \mathrm{O}_{2} \mathrm{~F}$} \\
\hline & $\Delta \mathrm{BE}$ & FWHM & $\Delta \mathrm{BE}$ & FWHM & $\Delta \mathrm{BE}$ & FWHM \\
\hline $\mathrm{P}$ & 14.2 & 3.3 & 14.5 & 2.7 & 13.3 & 2.5 \\
\hline Ch5 & 12.9 & 2.3 & 13.2 & 2.0 & 12.9 & 1.8 \\
\hline DCh5 & 13.0 & 4.3 & 14.4 & 2.6 & 13.5 & 3.2 \\
\hline Ch50 & 12.7 & 3.0 & 13.3 & 2.0 & 13.5 & 3.3 \\
\hline DCh50 & 12.7 & 3.2 & 13.4 & 2.0 & 13.5 & 3.3 \\
\hline
\end{tabular}

${ }^{a}$ Corresponding $\triangle \mathrm{BE}$ values for $\mathrm{V}^{3+}, \mathrm{V}^{4+}$ and $\mathrm{V}^{5+}$ in vanadium oxide references are $14.7,14.2$ and $12.8 \mathrm{eV}$, respectively. ${ }^{39}$

and $\mathrm{V}^{5+}$ in the region probed. The deviation from an average oxidation state of $3+$ might be related to surface oxidation, as seen also for other vanadium oxides. ${ }^{39}$ The mix of oxidation states is seen from the rather large FWHM of the V 2p peaks. This can be expected due to the disordered structure, where vanadium can be found with a different coordination of oxygen and fluorine, affecting the binding energy. Upon fifth charge all samples are as expected close to a fully oxidized $\mathrm{V}^{5+}$ state. After the following fifth discharge $\mathrm{Li}_{2} \mathrm{~V}_{0.5} \mathrm{Fe}_{0.5} \mathrm{O}_{2} \mathrm{~F}$ and $\mathrm{Li}_{2} \mathrm{~V}_{0.5} \mathrm{Ti}_{0.5} \mathrm{O}_{2} \mathrm{~F}$ return close to their respective pristine state, while the vanadium in $\mathrm{Li}_{2} \mathrm{VO}_{2} \mathrm{~F}$ is no longer redox active and stays in a highly oxidized state. For the $\mathrm{Li}_{2} \mathrm{VO}_{2} \mathrm{~F}$ material this reduced redox activity of vanadium has previously been suggested to be linked to a partial oxidation of oxygen forming reactive compounds that leads to a breakdown of the active material, starting at the surface. ${ }^{20}$ In this context both the $\mathrm{Li}_{2} \mathrm{~V}_{0.5} \mathrm{Fe}_{0.5} \mathrm{O}_{2} \mathrm{~F}$ and $\mathrm{Li}_{2} \mathrm{~V}_{0.5} \mathrm{Ti}_{0.5} \mathrm{O}_{2} \mathrm{~F}$ materials clearly show improved reversibility of the vanadium redox behavior. Still, after 50 cycles the materials show less to no redox activity of vanadium in the depth region probed by HAXPES. This trend can also be followed in the FWHM, which changes upon cycling. Especially on fifth discharge a broadening can be seen, indicating that some of the material can no longer return to its original state. This broadening is most significant for the unsubstituted material. The smaller FWHM after 50 cycles can be explained by a more uniform $\mathrm{V}^{5+}$ state of the probed material, in combination with that $\mathrm{V}^{5+}$ exhibits narrower peaks than $\mathrm{V}^{4+}$ and $\mathrm{V}^{3+}$, since $\mathrm{V}^{5+}$ does not have any unpaired valence electrons. ${ }^{39}$

To gain a deeper insight into the improved redox activity of the substituted materials it is interesting to look at the intensity ratio between vanadium and the metal oxide (MO) peak. ${ }^{20}$ In Table 2 the $\mathrm{V}$ : MO ratios are presented, with the oxygen content normalized to two for easy comparison. According to the structural formulas, the $\mathrm{V}$ content should be 1 for $\mathrm{Li}_{2} \mathrm{VO}_{2} \mathrm{~F}$ and 0.5 for $\mathrm{Li}_{2} \mathrm{~V}_{0.5} \mathrm{Fe}_{0.5} \mathrm{O}_{2} \mathrm{~F}$ and $\mathrm{Li}_{2} \mathrm{~V}_{0.5} \mathrm{Ti}_{0.5} \mathrm{O}_{2} \mathrm{~F}$. For the pristine materials the ratio is slightly higher than expected for the $\mathrm{Li}_{2} \mathrm{VO}_{2} \mathrm{~F}$ material, while for the $\mathrm{Li}_{2} \mathrm{~V}_{0.5} \mathrm{Fe}_{0.5} \mathrm{O}_{2} \mathrm{~F}$ and $\mathrm{Li}_{2} \mathrm{~V}_{0.5} \mathrm{Ti}_{0.5} \mathrm{O}_{2} \mathrm{~F}$ materials the ratio is slightly lower. Comparing charged and discharged samples, it is seen that the relative ratio is higher in the discharged samples for $\mathrm{Li}_{2} \mathrm{VO}_{2} \mathrm{~F}$ and $\mathrm{Li}_{2} \mathrm{~V}_{0.5} \mathrm{Fe}_{0.5} \mathrm{O}_{2} \mathrm{~F}$, while the $\mathrm{Li}_{2} \mathrm{~V}_{0.5} \mathrm{Ti}_{0.5} \mathrm{O}_{2} \mathrm{~F}$ material shows a small but opposite trend. For $\mathrm{Li}_{2} \mathrm{VO}_{2} \mathrm{~F}$ the $\mathrm{V}: \mathrm{MO}$ ratio increases
Table 2 Theoretical and experimentally measured ratios between vanadium and metal oxide for different samples ${ }^{a}$

\begin{tabular}{|c|c|c|c|}
\hline \multirow[b]{2}{*}{ Material } & \multicolumn{3}{|l|}{$\mathrm{V}: \mathrm{MO}$} \\
\hline & $\mathrm{Li}_{2} \mathrm{VO}_{2} \mathrm{~F}$ & $\mathrm{Li}_{2} \mathrm{~V}_{0.5} \mathrm{Ti}_{0.5} \mathrm{O}_{2} \mathrm{~F}$ & $\mathrm{Li}_{2} \mathrm{~V}_{0.5} \mathrm{Fe}_{0.5} \mathrm{O}_{2} \mathrm{~F}$ \\
\hline Ratio & $1.0: 2$ & $0.50: 2$ & $0.50: 2$ \\
\hline $\mathrm{P}$ & $1.2: 2$ & $0.33: 2$ & $0.42: 2$ \\
\hline Ch5 & $1.5: 2$ & $0.41: 2$ & $0.43: 2$ \\
\hline DCh5 & $1.9: 2$ & $0.35: 2$ & $0.74: 2$ \\
\hline Ch50 & $2.6: 2$ & $0.31: 2$ & $0.53: 2$ \\
\hline DCh50 & $5.2: 2$ & $0.28: 2$ & $0.75: 2$ \\
\hline
\end{tabular}

${ }^{a}$ To facilitate comparison the oxygen content is normalized to two according to the structural formula.

significantly during cycling together with a binding energy shift of the MO peak. As discussed in detail in another study, ${ }^{20}$ the relative increase and decrease of vanadium compared to oxygen can be coupled both to possible oxygen redox processes as well as the formation and dissolution of a surface layer containing vanadium. The same trend cannot be seen for the $\mathrm{Li}_{2} \mathrm{~V}_{0.5} \mathrm{Fe}_{0.5} \mathrm{O}_{2} \mathrm{~F}$ and $\mathrm{Li}_{2} \mathrm{~V}_{0.5} \mathrm{Ti}_{0.5} \mathrm{O}_{2} \mathrm{~F}$ materials. Only a slight increase of the $\mathrm{V}: \mathrm{MO}$ ratio is seen for $\mathrm{Li}_{2} \mathrm{~V}_{0.5} \mathrm{Fe}_{0.5} \mathrm{O}_{2} \mathrm{~F}$, while for $\mathrm{Li}_{2} \mathrm{~V}_{0.5} \mathrm{Ti}_{0.5} \mathrm{O}_{2} \mathrm{~F}$ a close to constant ratio is obtained up to 50 cycles. Additionally, only small binding energy shifts of the MO peak are seen $(<0.2 \mathrm{eV})$. These results clearly indicate that substitution with iron and titanium mitigates the detrimental reactions causing vanadium dissolution and incorporation in the surface layer and thus improves the chemical stability of the materials.

Looking further at the other transition metals (ESI, Fig. S12 $\dagger$ ), both iron and titanium are found to be partially redox active at the surface. Iron is found in a mix of $\mathrm{Fe}^{3+}$ and $\mathrm{Fe}^{2+}$ in the pristine material and upon cycling the $\mathrm{Fe}^{3+}$ content increases after fifth charge while more $\mathrm{Fe}^{2+}$ is found after subsequent discharge. Titanium is predominately found in the $\mathrm{Ti}^{4+}$ state for the pristine material, with some amount of $\mathrm{Ti}^{3+}$ upon discharge. As already mentioned for vanadium, the deviation from the $3+$ oxidation state indicates that an oxidized surface layer is present already after the synthesis of the materials. This kind of passivating surface film is often seen on cathode materials. ${ }^{54,55}$

The surface layer evolution during cycling is evaluated using the carbon spectra, as shown in Fig. 6. Here it is particularly interesting to look at the relative intensities between the carbon black (CB) bulk peak (shaded in red) and the hydrocarbon $(\mathrm{C}-\mathrm{H})$ surface peak. A relatively lower $\mathrm{CB}$ peak intensity signifies a thicker surface layer. Starting with the unsubstituted material (Fig. 6a), a buildup of a surface layer is seen upon charge, followed by its partial dissolution upon discharge. This is consistent with previous results for $\mathrm{Li}_{2} \mathrm{VO}_{2} \mathrm{~F}^{20}$ The substituted samples on the other hand show a stabilized surface after 50 cycles (similar Ch50/DCh50 spectra). Especially $\mathrm{Li}_{2} \mathrm{~V}_{0.5} \mathrm{Ti}_{0.5} \mathrm{O}_{2} \mathrm{~F}$ (Fig. 6b) shows a rather thin and stable surface layer with similar spectra for all samples. For $\mathrm{Li}_{2} \mathrm{~V}_{0.5} \mathrm{Fe}_{0.5} \mathrm{O}_{2} \mathrm{~F}$ the surface layer is of similar thickness compared to the $\mathrm{Li}_{2} \mathrm{VO}_{2} \mathrm{~F}$ sample, but the layer is more stable and no dissolution is observed after 50 cycles. 

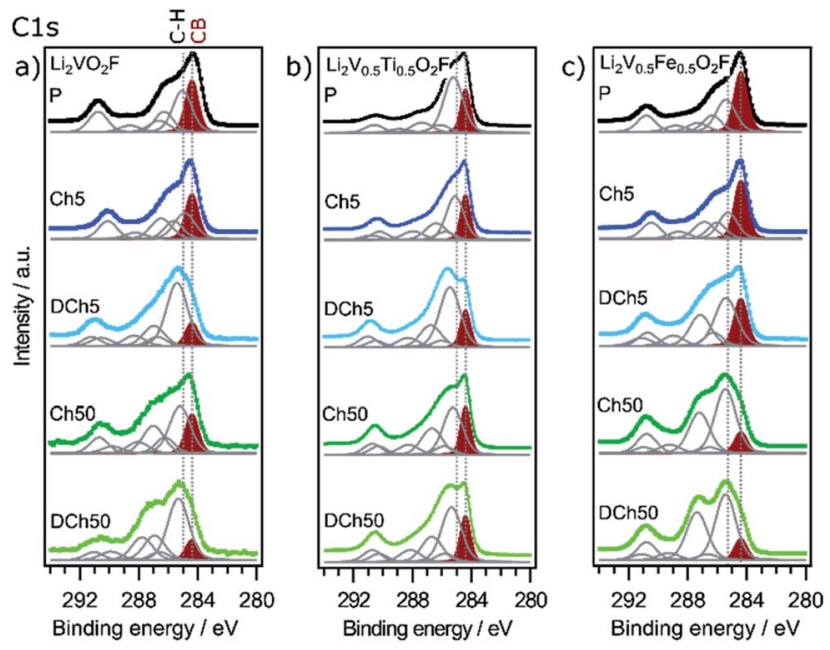

Fig. 6 C 1s photoelectron spectra of the three different materials in pristine, charged and discharged states after 5 and 50 cycles, obtained using a photon energy of $2005 \mathrm{eV}$ ( $\mathrm{a}$ and c) or $2350 \mathrm{eV}$ (b). Dotted lines are a guide to the eye to track shifts in the hydrocarbon $(\mathrm{C}-\mathrm{H})$ peak relative to the carbon black (CB) peak.

The other peaks in the C 1s spectra stem from the PVDF binder (two peaks at $\sim 286$ and $\sim 290 \mathrm{eV}$ ) and different carbon oxygen compounds (at $\sim 286.5,288$ and $290 \mathrm{eV}$ ), typically stemming from electrolyte degradation. The surface layers are seen to consist of mostly hydrocarbons and some $\mathrm{C}-\mathrm{O}$ compounds. On $\mathrm{Li}_{2} \mathrm{~V}_{0.5} \mathrm{Fe}_{0.5} \mathrm{O}_{2} \mathrm{~F}$ (Fig. 6c) the surface layer is built up with a relatively larger amount of $\mathrm{C}-\mathrm{O}$ compounds, probably stemming from electrolyte breakdown. The presence of a surface layer indicates that some side reactions occur for all materials, but a more stable layer, as found on the substituted materials, can limit the extent of these reactions by passivating the surface.

\section{Discussion}

Combining the results of the synthesis, the DFT calculations, the electrochemical experiments and the HAXPES analysis, the results can be discussed related to disorder of the structure and related to the electrochemical cycling behavior of the materials. The disorder in the crystal structure of the pristine TM-oxyfluorides leads to a distribution of oxidation states deviating from the original $3+$ state in the ordered structures for the presented compounds as has been revealed by the DFT calculations. The computed mixed $2+, 3+$, and $4+$ oxidation states for vanadium in $\mathrm{Li}_{2} \mathrm{VO}_{2} \mathrm{~F}$ are consistent with the HAXPES results, considering additional contribution of Li-deficiency and oxidation at the surface. ${ }^{\mathbf{1 4 , 2 0}}$ The DFT and HAXPES results further agree with the mixed $2+$ and $3+$ oxidation states of iron in $\mathrm{Li}_{2} \mathrm{~V}_{0.5} \mathrm{Fe}_{0.5} \mathrm{O}_{2} \mathrm{~F}$, which lead to a shift for vanadium to $4+$ and $5+$. For $\mathrm{Li}_{2} \mathrm{~V}_{0.5} \mathrm{Ti}_{0.5} \mathrm{O}_{2} \mathrm{~F}$, where the titanium oxidation state is $3+$ and $4+$, the substitution instead lowers the oxidation state of vanadium to $3+$. In addition, the DFT calculations showed that the metastable disordered rock salt structure was stabilized when partially substituting vanadium with iron or titanium.
The electrochemical cycling behavior of the substituted materials differs from that of $\mathrm{Li}_{2} \mathrm{VO}_{2} \mathrm{~F}$. Both substituted materials exhibit a significantly more stable cycling behavior but a lower discharge capacity. The differential capacity analysis reveals additional capacity contributions of $\mathrm{Li}_{2} \mathrm{~V}_{0.5} \mathrm{Ti}_{0.5} \mathrm{O}_{2} \mathrm{~F}$ compared to $\mathrm{Li}_{2} \mathrm{~V}_{0.5} \mathrm{Fe}_{0.5} \mathrm{O}_{2} \mathrm{~F}$ and $\mathrm{Li}_{2} \mathrm{VO}_{2} \mathrm{~F}$ indicating redox activity of titanium in the bulk. Whittingham et al. determined the oxidation state of vanadium in $\mathrm{Li}_{2} \mathrm{VO}_{2} \mathrm{~F}$ in the charged state by X-ray absorption spectroscopy. They observed an average oxidation state of only $4.2+$ when charged to $4.1 \mathrm{~V}$ vs. $\mathrm{Li} / \mathrm{Li}^{+}{ }^{14}$ Complete oxidation to $\mathrm{V}^{5+}$ could not be achieved. The HAXPES results of $\mathrm{Li}_{2} \mathrm{~V}_{0.5} \mathrm{Ti}_{0.5} \mathrm{O}_{2} \mathrm{~F}$ and $\mathrm{Li}_{2} \mathrm{~V}_{0.5} \mathrm{Fe}_{0.5} \mathrm{O}_{2} \mathrm{~F}$ confirm a partial redox activity of iron and titanium at the surface (ESI, Fig. S12 $\dagger$ ). Furthermore, we believe that some of the additional capacity of $\mathrm{Li}_{2} \mathrm{~V}_{0.5} \mathrm{Ti}_{0.5} \mathrm{O}_{2} \mathrm{~F}$ compared to $\mathrm{Li}_{2} \mathrm{~V}_{0.5} \mathrm{Fe}_{0.5} \mathrm{O}_{2} \mathrm{~F}$ stems from the fact that substitution with titanium promotes a complete use of the $\mathrm{V}^{3+} / \mathrm{V}^{5+}$ redox couple. Further analysis by X-ray absorption techniques may shed light on the different redox reactions occurring in the bulk material.

In recent reports, DRS materials are cycled to high potentials up to $4.8 \mathrm{~V} v s$. $\mathrm{Li} / \mathrm{Li}^{+}$, which facilitates anionic redox activity of oxygen in the lattice that leads to additional capacity contribution. ${ }^{11,14-16,21}$ Materials containing $\mathrm{Ti}, \mathrm{Li}_{1.2} \mathrm{Ti}_{0.4} \mathrm{Mn}_{0.4} \mathrm{O}_{2}$ for instance, experimentally sustain a stable oxygen-redox reaction above 4.1 vs. $\mathrm{Li} / \mathrm{Li}^{+} .^{10}$ The observed shift in binding energy of the MO peak together with the relative changes in intensity between the MO peak and vanadium indicates that such anionic redox activity occurs in the surface region of the $\mathrm{Li}_{2} \mathrm{VO}_{2} \mathrm{~F}$ material already when cycling to $4.1 \mathrm{~V}$ vs. $\mathrm{Li} / \mathrm{Li}^{+}{ }^{56}$ In $\mathrm{Li}_{2} \mathrm{VO}_{2} \mathrm{~F}$ this is believed to create highly reactive oxygen atoms in the lattice leading to the instability of the surface, as discussed in more detail in the work of Källquist et al. ${ }^{20}$ The reaction between the oxidized lattice oxygen and the electrolyte creates an interfacial layer rich in vanadium in oxidation state $5+. \mathrm{Li}_{2} \mathrm{~V}_{0.5} \mathrm{Ti}_{0.5} \mathrm{O}_{2} \mathrm{~F}$ and $\mathrm{Li}_{2} \mathrm{~V}_{0.5} \mathrm{Fe}_{0.5} \mathrm{O}_{2} \mathrm{~F}$ show a higher reversibility of the $\mathrm{V}$ redox reaction according to the differential capacity analysis and the HAXPES results. In the $\mathrm{d} Q / \mathrm{d} V$ plot, the substituted materials show a reduced irreversible capacity contribution above $3.5 \mathrm{~V}$ up to. $4.1 \mathrm{~V} v s . \mathrm{Li} / \mathrm{Li}^{+}$. At the same time, the HAXPES data only show small changes of the $\mathrm{V}$ : MO-ratio and the binding energy of the MO peak after 50 cycles for $\mathrm{Li}_{2} \mathrm{~V}_{0.5} \mathrm{Ti}_{0.5} \mathrm{O}_{2} \mathrm{~F}$ and $\mathrm{Li}_{2} \mathrm{~V}_{0.5} \mathrm{Fe}_{0.5} \mathrm{O}_{2} \mathrm{~F}$. Together this suggests a reduced reactivity of the lattice oxygen species at the surface in these new materials when cycled to 4.1 $\mathrm{V}$ vs. $\mathrm{Li} / \mathrm{Li}^{+}$. We propose this as an explanation for the improved cycling stability. This is further supported by the cycling performance when the materials are cycled up to $4.5 \mathrm{~V}$ vs. $\mathrm{Li} / \mathrm{Li}^{+}$. These results (see ESI, Fig. S13†) show additional contribution to the capacity for all three compounds, possibly originating from anionic redox activity, but are also accompanied by a reduced cycling stability.

Additional contribution to the cycling stability likely comes from mitigation of the dissolution and rebuilding of the surface layer for the substituted materials that otherwise is seen on $\mathrm{Li}_{2} \mathrm{VO}_{2} \mathrm{~F}$. Although the thickness of the surface layers on $\mathrm{Li}_{2} \mathrm{~V}_{0.5} \mathrm{Ti}_{0.5} \mathrm{O}_{2} \mathrm{~F}$ and $\mathrm{Li}_{2} \mathrm{~V}_{0.5} \mathrm{Fe}_{0.5} \mathrm{O}_{2} \mathrm{~F}$ varies, both are to a large part preserved during cycling. This is in agreement with a recent 
study of Takeda et al. on $\mathrm{Li}_{2.1} \mathrm{Ti}_{0.2} \mathrm{Mo}_{0.7} \mathrm{O}_{2} \mathrm{~F}$ showing a reduced dissolution of Mo when Ti is in the structure. ${ }^{17}$

Coupling these results to the electrochemical performance the improved cycling behavior of the Fe- or Ti-substituted materials can be summarized by a mitigated reactivity of the surface that previously has been perceived as one of the main reasons for capacity fading in Li-rich DRS materials. ${ }^{10,20,57}$

\section{Conclusions}

We have demonstrated the successful approach of improving the cycling stability of Li-rich vanadium disordered rock salt oxyfluoride cathodes by stabilization of the structure with $\mathrm{Ti}^{3+}$ or $\mathrm{Fe}^{3+}$. Two new disordered rock salt compounds, $\mathrm{Li}_{2} \mathrm{~V}_{0.5} \mathrm{Fe}_{0.5} \mathrm{O}_{2} \mathrm{~F}$ and $\mathrm{Li}_{2} \mathrm{~V}_{0.5} \mathrm{Ti}_{0.5} \mathrm{O}_{2} \mathrm{~F}$, have been successfully synthesized by mechanochemical ball milling. The materials were characterized by synchrotron X-ray diffraction followed by an extensive analysis of the crystal structure by Rietveld refinement and transmission electron microscopy. By using the special quasi-random structure approach in density functional theory calculations, a distribution of oxidation states of the transition metal in the structure was revealed. The theoretical model further predicted an improvement of the structural stability for disordered rock salt $\mathrm{Li}_{2} \mathrm{~V}_{0.5} \mathrm{Fe}_{0.5} \mathrm{O}_{2} \mathrm{~F}$ and $\mathrm{Li}_{2} \mathrm{~V}_{0.5} \mathrm{Ti}_{0.5} \mathrm{O}_{2} \mathrm{~F}$ compared to unsubstituted $\mathrm{Li}_{2} \mathrm{VO}_{2} \mathrm{~F}$. The stabilizing effect on the structure further manifests in a significantly improved cycling stability over 50 cycles. HAXPES analysis of cycled electrodes supports our hypothesis and shows improved surface stability of the substituted materials. The cycling stability of the substituted compounds is significantly improved and supports our hypothesis of stabilizing the disordered rock salt structure of oxyfluorides in the bulk and at the surface with elements promoting the DRS structure $\left(\mathrm{Fe}^{3+}\right.$ and $\left.\mathrm{Ti}^{3+}\right)$. Optimizing the TM stoichiometry by reducing the amount of stabilizing elements (e.g. $\mathrm{Ti}^{3+}$ or $\mathrm{Fe}^{3+}$ ) will help to increase discharge capacities. This work is one step further in understanding the structural and electrochemical cycling stability of DRS materials as a promising class of Cofree Li-ion insertion cathode materials.

\section{Author contributions}

CB and JC planned the project. JC proposed the idea of DRS structure and capacity stabilization through substitution. CB, JC and AS synthesized the materials. CB performed the electrochemical measurements with the help of FK. The PXRD synchrotron data were acquired by REJ with the help of CB and PN. The PXRD data were analysed by CB with the help of REJ and JC. HAXPES samples were prepared by IK and measurements were performed by IK, AN and MH. HAXPES analysis was conducted by IK. Computational investigations were performed by JHC. TEM data were acquired by FRZ with the help of JMA. The manuscript was written by CB with the help of IK, JHC and MH. The manuscript was revised with the help of all authors.

\section{Conflicts of interest}

There are no conflicts to declare.

\section{Acknowledgements}

This project has received funding from the European Union's Horizon 2020 research and innovation program (FET-OPEN project "LiRichFCC") under grant agreement No. 711792. This research used resources of the Advanced Photon Source, an Office of Science User Facility operated for the U.S. Department of Energy (DOE) office of Science by Argonne National Laboratory and was supported by the U.S. DOE under contract No. DEAC02-06CH11357. DANSCATT is acknowledged for covering travel expenses in relation to the synchrotron experiment. The research leading to the HAXPES result has been supported by the project CALIPSOplus under the Grant Agreement 730872 from the EU Framework Programme for Research and Innovation HORIZON 2020. We acknowledge Diamond Light Source for time on Beamline I09 under Proposal 19602 and HZB for allocated synchrotron radiation beamtime on beamline KMC-1 at BESSY II. The work is part of the platform CELEST (Center for Electrochemical Storage Ulm-Karlsruhe).

\section{Notes and references}

1 J. B. Goodenough and K.-S. Park, J. Am. Chem. Soc., 2013, 135, 1167-1176.

2 M. Armand and J.-M. Tarascon, Nature, 2008, 451, 652-657.

3 M. Winter, J. O. Besenhard, M. E. Spahr and P. Novák, Adv. Mater., 1998, 10, 725-763.

4 J. B. Goodenough and Y. Kim, Chem. Mater., 2010, 22, 587603.

5 R. Chen, S. Ren, M. Knapp, D. Wang, R. Witter, M. Fichtner and H. Hahn, Adv. Energy Mater., 2015, 5, 1401814.

6 A. Abdellahi, A. Urban, S. Dacek and G. Ceder, Chem. Mater., 2016, 28, 5373-5383.

7 J. Lee, A. Urban, X. Li, D. Su, G. Hautier and G. Ceder, Sci. 80, 2014, 343, 519-522.

8 A. Urban, J. Lee and G. Ceder, Adv. Energy Mater., 2014, 4, 1400478.

9 R. Chen, S. Ren, M. Yavuz, A. A. Guda, V. Shapovalov, R. Witter, M. Fichtner and H. Hahn, Phys. Chem. Chem. Phys., 2015, 17, 17288-17295.

10 N. Yabuuchi, M. Nakayama, M. Takeuchi, S. Komaba, Y. Hashimoto, T. Mukai, H. Shiiba, K. Sato, Y. Kobayashi, A. Nakao, M. Yonemura, K. Yamanaka, K. Mitsuhara and T. Ohta, Nat. Commun., 2016, 7, 13814.

11 N. Yabuuchi, M. Takeuchi, M. Nakayama, H. Shiiba, M. Ogawa, K. Nakayama, T. Ohta, D. Endo, T. Ozaki, T. Inamasu, K. Sato and S. Komaba, Proc. Natl. Acad. Sci. U. S. A., 2015, 112, 7650-7655.

12 J. Lee, D. H. Seo, M. Balasubramanian, N. Twu, X. Li and G. Ceder, Energy Environ. Sci., 2015, 8, 3255-3265.

13 N. Takeda, S. Hoshino, L. Xie, S. Chen, I. Ikeuchi, R. Natsui, K. Nakura and N. Yabuuchi, J. Power Sources, 2017, 367, 122129. 
14 X. Wang, Y. Huang, D. Ji, F. Omenya, K. Karki, S. Sallis, L. F. J. Piper, K. M. Wiaderek, K. W. Chapman, N. A. Chernova and M. S. Whittingham, J. Electrochem. Soc., 2017, 164, A1552-A1558.

15 S. Ren, R. Chen, E. Maawad, O. Dolotko, A. A. Guda, V. Shapovalov, D. Wang, H. Hahn and M. Fichtner, Adv. Sci., 2015, 2, 1500128.

16 R. A. House, L. Jin, U. Maitra, K. Tsuruta, J. W. Somerville, D. P. Förstermann, F. Massel, L. Duda, M. R. Roberts and P. G. Bruce, Energy Environ. Sci., 2018, 11, 926-932.

17 N. Takeda, I. Ikeuchi, R. Natsui, K. Nakura and N. Yabuuchi, ACS Appl. Energy Mater., 2019, 2, 1629-1633.

18 T. Matsuhura, Y. Tsuchiya, K. Yamanaka, K. Mitsuhura, T. Ohta and N. Yabuuchi, Electrochemistry, 2016, 84, 797801.

19 M. Freire, N. V. Kosova, C. Jordy, D. Chateigner, O. I. Lebedev, A. Maignan and V. Pralong, Nat. Mater., 2016, 15, 173-177.

20 I. Källquist, A. J. Naylor, C. Baur, J. Chable, J. Kullgren, M. Fichtner, K. Edstrom, D. Brandell and M. Hahlin, Chem. Mater., 2019, 31, 6084-6096.

21 J. Lee, D. A. Kitchaev, D.-H. Kwon, C.-W. Lee, J. K. Papp, Y.-S. Liu, Z. Lun, R. J. Clément, T. Shi, B. D. McCloskey, J. Guo, M. Balasubramanian and G. Ceder, Nature, 2018, 556, 185-190.

22 A. P. Hammersley, ESRF Intern. Rep.

23 A. P. Hammersley, S. O. Svensson, M. Hanfland, A. N. Fitch and D. Hausermann, High Pressure Res., 1996, 14, 235-248.

24 A. P. Hammersley, S. O. Svensson and A. Thompson, Nucl. Instrum. Methods Phys. Res., Sect. A, 1994, 346, 312-321.

25 A. A. Coelho, J. Appl. Crystallogr., 2018, 51, 210-218.

26 G. Kresse and J. Hafner, Phys. Rev. B: Condens. Matter Mater. Phys., 1993, 47, 558-561.

27 G. Kresse and J. Hafner, Phys. Rev. B: Condens. Matter Mater. Phys., 1994, 49, 14251-14269.

28 G. Kresse and J. Furthmüller, Comput. Mater. Sci., 1996, 6, 15-50.

29 G. Kresse and J. Furthmüller, Phys. Rev. B: Condens. Matter Mater. Phys., 1996, 54, 11169-11186.

30 P. E. Blöchl, Phys. Rev. B: Condens. Matter Mater. Phys., 1994, 50, 17953-17979.

31 J. P. Perdew, K. Burke and M. Ernzerhof, Phys. Rev. Lett., 1996, 77, 3865-3868.

32 V. I. Anisimov, J. Zaanen and O. K. Andersen, Phys. Rev. B: Condens. Matter Mater. Phys., 1991, 44, 943-954.

33 M. Cococcioni and S. de Gironcoli, Phys. Rev. B: Condens. Matter Mater. Phys., 2005, 71, 035105.

34 H. J. Monkhorst and J. D. Pack, Phys. Rev. B: Solid State, 1976, 13, 5188-5192.

35 F. Schaefers, M. Mertin and M. Gorgoi, Rev. Sci. Instrum., 2007, 78, 123102 .
36 T.-L. Lee and D. A. Duncan, Synchrotron Radiation News, 2018, 31, 16-22.

37 U. Guide, C. J. Powell, M. S. Division and A. Jablonski, Nat'l Std. Ref. Data Ser. (NIST NSRDS).

38 K. A. Persson, D. Skinner, W. Chen, S. Cholia, G. Hautier, D. Gunter, S. P. Ong, S. Dacek, W. D. Richards, A. Jain and G. Ceder, APL Mater., 2013, 1, 011002.

39 M. C. Biesinger, L. W. M. Lau, A. R. Gerson and R. S. C. Smart, Appl. Surf. Sci., 2010, 257, 887-898.

40 J. F. Moulder, W. F. Stickle, P. E. Sobol, K. D. Bomben and J. Chastain, Handbook of X-Ray Photoelectron Spectroscopy A Reference Book of Standard Spectra for Identification and Interpretation of XPS Data, Perkin-Elmer Corporation, 1992.

41 T. C. Lin, G. Seshadri and J. A. Kelber, Appl. Surf. Sci., 1997, 119, 83-92.

42 M. C. Biesinger, B. P. Payne, A. P. Grosvenor, L. W. M. Lau, A. R. Gerson and R. S. C. Smart, Appl. Surf. Sci., 2011, 257, 2717-2730.

43 J. H. Scofield, Theoretical Photoionization Cross Sections from 1 to $1500 \mathrm{keV}$, U.S. Atomic Energy Commission, 1973.

44 V. Šepelák, A. Düvel, M. Wilkening, K. D. Becker and P. Heitjans, Chem. Soc. Rev., 2013, 42, 7507-7520.

45 C. Baur, J. Chable, F. Klein, V. S. K. Chakravadhanula and M. Fichtner, ChemElectroChem, 2018, 5, 1484-1490.

46 R. D. Shannon, Acta Crystallogr., Sect. A: Cryst. Phys., Diffr., Theor. Gen. Crystallogr., 1976, 32, 751-767.

47 G. Williamson and W. Hall, Acta Metall., 1953, 1, 22-31.

48 A. Urban, A. Abdellahi, S. Dacek, N. Artrith and G. Ceder, Phys. Rev. Lett., 2017, 119, 1-6.

49 A. Urban, I. Matts, A. Abdellahi and G. Ceder, Adv. Energy Mater., 2016, 6, 1600488.

50 X. Wang, Y. Huang, D. Ji, F. Omenya, K. Karki, S. Sallis, L. F. J. Piper, K. M. Wiaderek, K. W. Chapman, N. A. Chernova and M. S. Whittingham, J. Electrochem. Soc., 2017, 164, A1552-A1558.

51 R. Chen, R. Witte, R. Heinzmann, S. Ren, S. Mangold, H. Hahn, R. Hempelmann, H. Ehrenberg and S. Indris, Phys. Chem. Chem. Phys., 2016, 18, 7695-7701.

52 E. Peled and S. Menkin, J. Electrochem. Soc., 2017, 164, A1703-A1719.

53 B. Philippe, M. Hahlin, K. Edström, T. Gustafsson, H. Siegbahn and H. Rensmo, J. Electrochem. Soc., 2015, 163, A178-A191.

54 K. Xu, Chem. Rev., 2014, 114, 11503-11618.

55 D. Aurbach, B. Markovsky, G. Salitra, E. Markevich, Y. Talyossef, M. Koltypin, L. Nazar, B. Ellis and D. Kovacheva, J. Power Sources, 2007, 165, 491-499.

56 G. Assat, D. Foix, C. Delacourt, A. Iadecola, R. Dedryvère and J.-M. Tarascon, Nat. Commun., 2017, 8, 2219.

57 J. Lee, J. K. Papp, R. J. Clément, S. Sallis, D.-H. Kwon, T. Shi, W. Yang, B. D. McCloskey and G. Ceder, Nat. Commun., 2017, 8, 981. 